Article

\title{
Contested Health Care System in Berlin: Are Illegalized Migrants Becoming Urban Citizens?
}

\author{
Holger Wilcke ${ }^{1, *}$ and Rosa Manoim ${ }^{2}$ \\ ${ }^{1}$ Berlin Institute of Migration and Integration Research, Humboldt University of Berlin, 10099 Berlin, Germany; \\ E-Mail: holger.wilcke@hu-berlin.de \\ 2 Department of Social Sciences, University of the Witwatersrand, 2000 Johannesburg, South Africa; \\ E-Mail: rosa.manoim@students.wits.ac.za \\ * Corresponding author
}

Submitted: 30 June 2019 | Accepted: 10 November 2019 | Published: 28 November 2019

\begin{abstract}
This article argues for an urban citizenship perspective which explores the struggle for rights and the everyday practices of illegalized migrants. Analyzing the concept of Anonymized Health Certificates as a result of such a struggle allows for examination of urban citizenship in this context. The implementation of the Anonymized Health Certificates program would facilitate access to medical care for people who live in the city of Berlin but are excluded from this right due to their lack of residency status. However, such a perspective also makes it possible to examine the limitation of the Anonymized Health Certificates, which would allow illegalized migrants in Berlin to circumvent access barriers, while at the same time the exclusion mechanisms of these barriers would remain uncontested at the national level. Whilst Anonymize Health Certificates will greatly improve access to medical care, illegalized migrants have by no means been passive subjects and have been actively rejecting their exclusion from health care: Practices include sharing health insurance cards with friends, visiting doctors who help for free as a form of solidarity, and sharing information about these doctors within their social networks. Even if they do not contest the social order visibly, they refuse to passively accept their social exclusion. Illegalized migrants perform such practices of urban citizenship in their everyday life as they actively take ownership of their rights to participate in urban life, even whilst being formally denied these rights.
\end{abstract}

\section{Keywords}

Anonymized Health Certificates; illegalized migration; medical care; urban citizenship

\section{Issue}

This article is part of the issue "Inclusion through Enacted Citizenship in Urban Spaces" edited by Rachel Kurian (Erasmus University Rotterdam, The Netherlands) and Helen Hintjens (Erasmus University Rotterdam, The Netherlands).

(C) 2019 by the authors; licensee Cogitatio (Lisbon, Portugal). This article is licensed under a Creative Commons Attribution 4.0 International License (CC BY).

\section{Introduction}

Up until summer 2019, undocumented migrants in Germany were de facto excluded from accessing medical care. Without documents, it was virtually impossible to join the public health insurance system which is required in order to receive medical care. Moreover, Social Welfare Offices (Sozialämter), which would have to cover the costs of certain treatments for illegalized migrants, failed to be a viable option as they were obliged to report to the Foreigners Registration Office
(Ausländerbehörde) which could result in deportation. In Berlin, this dilemma is now resolved. Through the implementation of Anonymized Health Certificates, the access to medical care for people who have no formal access due to their lack of official residency is fundamentally simplified. This certificate allows them to access medical care without disclosing their residency status and thus risking deportation.

In this article, we will discuss the processes that led to the enactment of the Anonymized Health Certificate. We will argue that the Medibüro was a key player in 
this. The Medibüro is a grassroots initiative which has been fighting for equal access to medical care for all, for more than 20 years now. We will analyze their struggles and campaigns as solidarity forms of urban citizenship which led to the implementation of the Anonymized Health Certificate by the current government of Berlin. Furthermore, we will focus on the everyday practices of illegalized migrants who are living under complicated conditions of disenfranchisement. Even before the Anonymized Health Certificate was implemented, illegalized migrants developed strategies to get access to medical care and to participate in social life. We will emphasize the performative dimension of citizenship and argue that even without access to fundamental rights, illegalized migrants are active subjects who refuse to passively accept social exclusion.

Methodologically, this article was based on participatory observations, document analyses, and, most importantly, on interviews conducted with illegalized migrants and urban actors between 2014-2019. To ensure anonymity, the names of these participants have been altered in this article. In the following section we will shortly discuss the currently debated concepts of (urban) citizenship before we describe the effects of exclusionist mechanisms in the field of medical care in Berlin. Then we will focus on the transformative processes that led to the implementation of the Anonymized Health Certificates. Finally, we look at the strategies with which illegalized migrants find ways to resist their exclusion and disenfranchisement.

\section{Urban Citizenship}

Urban citizenship is a counter-concept to the idea of citizenship as formal membership to a nation state with a set of obligations and rights that come with it (McNevin, 2013, p. 198; Schilliger, 2018, p. 17). Citizenship as formal membership attributes access to social rights and possibilities of participation in society according to status. In contrast, a critical perspective on citizenship challenges such purely legal conceptions and emphasizes the contingency of formal citizenship by focusing on the claims for rights and the conflicting social disputes over participation (Hess \& Lebuhn, 2014, p. 20). Egin Isin (2009) demonstrates how the understanding of citizenship has been subject to constant reconfigurations since the times of the polis due to the claims of those who have been denied equal rights. Therefore, it is less a question of "who is a citizen" than one of "what makes the citizen" (Isin, 2009, p. 383).

Here the city plays a central role and the debates on urban citizenship focus on the rescaling of citizenship and belonging from a nation-state to an urban scale (Darling, 2017; Hess \& Lebuhn, 2014; Nicholls, 2016). In fact, the city governments can act as a counterpart to national border policies and exclusion mechanisms. The 'Don't Ask Don't Tell' policy in Toronto or the implementation of the Municipal ID Card in New York are two examples of this. Both policies follow the idea of making the legal status less relevant for the access to rights and participation in urban life (Rygiel, Ataç, Köster-Eiserfunke, \& Schwiertz, 2015, p. 9).

The Anonymized Health Certificate can be regarded as an urban policy that opposes the exclusionary mechanisms of national border and migration policies. But just like the campaigns of New York's 'Make the Road' network and the Sanctuary City movement in Toronto, the Anonymized Health Certificate did not come out of nowhere. To understand citizenship as a process means shifting the focus away from legal regulations and beginning instead to scrutinize the underlying processes of negotiation and conflict. The concept of urban citizenship consequently invites us "to focus on the actual sites where citizenship is negotiated in day-to-day life, and where forms of solidarity are exercised within urban communities" (Schilliger, 2019, p. 36). In the following two sections we will discuss the extent to which the campaigns of the Medibüro can be seen as "acts in solidarity with those who have undertaken an act of unauthorised migration" (Squire, 2017, p. 267).

Such a procedural understanding of citizenship also directs attention towards migrants as active political subjects. Illegalized migrants have their own strategies to deal with exclusions and find ways in their everyday lives to gain access to medical care, regardless of the existence of Anonymized Health Certificates. These everyday practices entail moments of political subjectivation, in which citizenship from below "is seized (not bestowed) and transformed (not replicated) in performative acts... which rupture prevailing assumptions about what citizenship is, where it applies, how it has come to be constituted and who does the work that citizens do" (McNevin, 2013, p. 198). However, we will discuss to which extent such "acts of citizenship" (Isin, 2008, p. 18) encompass visibility or whether political subjectivity also manifests in imperceptible performances of illegalized migrants.

\section{The Excluding Mechanisms of the Health Care System}

Don't get sick. That's the first rule. If you get sick, you have to get back on your feet quickly. (Interview, Noah)

Illegalized persons are not allowed to register for public health insurance without official papers. Without health insurance, seeing a doctor becomes nearly impossible. As said before, the insurance companies would have to inform the Foreigners Registration Office of the applicant's illegalized status, which would increase the risk of deportation. The Foreigners Registration Office issues residence permits, extends temporary residence documents, issues exit requests, and orders deportations. Noah describes that becoming ill as an illegalized person is not an option, because illness is connected to fears and uncertainties. Any sickness may lead to the loss of 
a job. Any injury may result in high costs. For a person without official documents there is no legal right to social welfare benefits. Without health insurance, there is the very likely risk of being obliged to cover the cost of treatment yourself. Accordingly, illegalized migrants try as best as they can to avoid pregnancies, injuries, or illnesses as best as they possibly can (cf. Wilcke, 2018, p. 193-194). This is already an expression of the precarious situation in which undocumented migrants find themselves. The uncertainties in illegality, which also affect other areas of life such as living or working, increase an individual's psychosocial stress and thus also the probability of becoming ill. If illegalized migrants do fall ill or get injured, illnesses and injuries are often ignored or go untreated. Besides, self-treatment and selfmedication is a widespread practice among illegalized migrants (Huschke, 2013, p. 249). For many illegalized people, visiting a doctor is out of question, which has to do with the de facto exclusion from public health care.

According to the Welfare Law for Asylum Seekers (Asylbewerberleistungsgesetz), illegalized persons are formally allowed to receive emergency treatment. But the unclear information about their legal rights, combined with the general fear of potential deportations when contacting official institutions, produce significant barriers for illegalized migrants (cf. Wilcke, 2018, p. 199). In any case, access to regular medical care is completely obstructed. Before getting a doctor appointment or medical treatment, the illegalized migrant would have to apply at the Social Welfare Office which is obliged to report to the Foreigners Registration Office (Bartholome, Groß, \& Misbach, 2010, p. 22). The uncertainties and fears of illegalized migrants, which often lead to the avoidance of medical treatment, are tied precisely to this obligation of public authorities to report the person's residence status. This fear, that their lack of legal status will be revealed to the authorities and the threat of deportation that this results in, can be described as deportability (de Genova, 2002, p. 438). In this way, illegalized migrants are excluded from medical care.

As the exclusion of people from medical care stands in moral conflict with the value system of the Federal Republic of Germany, the policy came under scrutiny in 2005. On the basis of the coalition agreement between the Christian Democrats (Christian Democratic Union [CDU]/Christian Social Union [CSU]) and Social Democrats (Social Democratic Party of Germany [SPD]), the Federal Ministry of the Interior discussed the removal of the obligation for state institutions to report to the Foreigners Registration Office-as established in the $\S 87$ of the Residence law-in 2005. In its concluding report, the ministry states that the obligation should be maintained unchanged as this legislation provides the state with a means of migration control that helps to enforce the right of residence. Furthermore, they make it clear that a deterrent effect for migrants planning to come to Germany without regular papers is intended (Bundesministerium des Innern, 2007, pp. 40-41). Since then, the legislation has not been called into question by any Federal Government. Here, the function of formal citizenship manifests itself through its uneven assignment of rights to people, thus categorizing them and fragmenting their possibilities of participation (Schilliger, 2018, pp. 19-20). This statement shows that the borders of the European migration regime do not only run along the Schengen external border and consist of fences, thermal imaging cameras, and border guards. Rather, the borders are dispersed within the states to sites such as the train station, the Federal employment agency, the school, or, in this case, the hospital (Balibar, 2004; Nyers, 2008; Squire, 2011). They are also inscribed in legislation in a variety of ways and often run through European metropolises and are extremely effective. As a result, state institutions such as the Social Welfare Office become border guards, whose exclusionary practices can be seen as an everyday act of bordering which differentiates between those who have access to certain rights und those who do not (Yuval-Davis, Wemyss, \& Cassidy, 2018). Thus, the health system has a bordering effect in two ways. For illegalized migrants who already live here, the availability of medical care is restricted. And for those who want to come to Germany but have no legal ways to enter, there is an intention to convey the message that there are effective internal borders and mechanisms of exclusion, even for those who manage to cross the external borders.

Nevertheless, the $\S 87$ obligation and its bordering effects are not uncontested. While a change is not foreseeable at the federal level, the concept of the Anonymized Health Certificates is being tested in the City of Berlin.

\section{Anonymized Health Certificates}

In 2016, a new government was formed in Berlin by the Social Democrats (SPD), the Green Party (Bündnis90/Die Grünen) and The Left Party (Die Linke), which included the creation of the Anonymized Health Certificates in their coalition agreement. This alliance of three parties represents a more open and inclusive approach to migration politics than the previous state government of Berlin or the federal government, which were both formed by a coalition of SPD and Christian Democrats (CDU). 2018 saw the implementation of a 'clearing office for uninsured people' which received $€ 1,5 \mathrm{M}$ in funding in 2018 and 2019. One of the aims of this institution is reintegrating people without health insurance into standard care. In the case of illegalized migrants who areas described previously-excluded from public insurance and health care, the clearing office issues Anonymized Health Certificates. It provides illegalized migrants with the medical care which they are legally entitled to under the Asylum Seekers Benefits Act without having to fear the transmission of their data to the Foreigners Registration Office. For this reason, the responsibility was transferred from the Social Welfare Office to a medically managed health care center which is bound to con- 
fidentiality and not obliged to report to other authorities. Here, it becomes apparent that borders are not set in stone but represent contested and malleable constructions (cf. Lebuhn, 2014, p. 229). The introduction of Anonymized Health Certificates exemplifies how urban governments have the capacity to challenge exclusionary national policies of citizenship by circumventing them a local level (Rygiel et al., 2015, p. 9; Schilliger, 2019, p. 36). Moreover, the clearing office considers itself a contact point for all residents of Berlin. This demonstrates a new conception of citizenship which does not define belonging to a city through ethnicizing-culturalist categorizations of official documents but through local residence and participation in the city (Gilbert \& Dikeç, 2008).

To follow the theoretical perspective of citizenship as a process, we have to consider another actor, which-we argue-was central for the implementation of Anonymized Health Certificates in Berlin in 2019. The Medibüro is an antiracist grassroots initiative, which was founded in Berlin in 1996. It has continuously provided illegalized migrants with access to medical care. In this way, the Medibüro gives people access to fundamental rights that they are actually excluded from and thus enables their participation in urban life, which already can be understood as a solidarity-based practice of urban citizenship (Nyers \& Rygiel, 2012, p. 10; Squire, 2017, p. 267). In the 90s, the work was organized clandestinely, resulting in conditions which were even more precarious than they are today. Even the act of supporting illegalized migrants purely with medical care was criminalized by both state and city authorities. Doctors or intermediaries could be prosecuted for the crime of aiding and abetting an illegal stay (Dickel \& Schröder, 2013 , p. 9). Since its founding, the work of Medibüro includes more than just the practical support of illegalized migrants. It regards itself as a political actor that stands in solidarity with illegalized migrants and campaigns "to counter the racist exclusion of migrants from social legislation and regular health care" (Groß, 2005, p. 20). Now, however, to the government of Berlin, the Medibüro is a legitimate political initiative. Public authorities turn to the Medibüro for advice and assistance and have praised it for its excellent voluntary work (Dickel \& Schröder, 2013, p. 9). Beyond that, the senate administration has invited the Medibüro to participate in talks on how to facilitate the access to medical care for illegalized migrants. In this context, the senate administration has offered to support the practical work of the Medibüro with funding. However, this would have resulted in the stabilization of parallel structures of medical care contradicting the political premise of equal access to medical care for all regardless of residency status. In consequence, the Medibüro declined the offer and began to advocate for the introduction of Anonymized Health Certificates, which they had developed into a concrete program (Huschke, 2013, p. 188). In the wake of these developments, the senate administration founded a working group which was tasked to examine the imple- mentability of this program (Groß, 2009, p. 25). This necessitated an involvement of the Senate Department of Labour and Social Affairs as well as Interior. Throughout further talks, the Senate Department of Interior blocked the implementation of Anonymized Health Certificates program both under SPD/CDU as well as SPD/Die Linke led governments in Berlin. The idea of providing public funding for social benefits without disclosing individual identity was rejected by the Senate Department of Interior (Medibüro, 2016, p. 49).

Nevertheless, the Medibüro continued to fight for the right to health and the introduction of the Anonymized Health Certificates program. They collaborated with the senate and contributed their practical experiences. Without these efforts, the program would not have been featured in the coalition agreement of the current state government. We argue that the very moment in which the concept of the Anonymized Health Certificates was put on the political agenda was an act of solidarity with those who had been claiming their rights to stay and participate in society by simply living their lives (Ataç, Rygiel, \& Stierl, 2016, p. 530; Squire, 2017 , p. 267) By initiating the idea of the Anonymized Health Certificates and campaigning for its implementation, the Medibüro raised awareness regarding the disenfranchisement of certain migrant groups for whom it is risky to become visible. In this way it questioned the given script of denied rights and denied participation possibilities (Rygiel et al., 2015, p. 9).The Medibüro strategically used the possibilities of the urban (Bauder, 2016) to claim rights to the city by proposing a concrete concept that enhances the idea of urban citizenship in which all residents of the city have the same rights, regardless of their formal citizenship, their nationality, or their residency status (Nyers \& Rygiel, 2012, p. 10; Rygiel et al., 2015, p. 9).

Many conflicts remain unresolved. Jointly with Solidarity City Berlin, The Medibüro criticizes the implementation of the program by the current government due to apparent weaknesses such as the insufficient funding (Medibüro, 2019). And other dilemmas arise: On the one hand, the Anonymized Health Certificates will have the pragmatic effect of providing people with access to medical care. On the other hand, the existing exclusion mechanisms stay uncontested. The $\$ 87$ of the Residence Law, the very reason for the need for Anonymized Health Certificates, remains untouched. In addition, the Anonymized Health Certificates only entitle its holders to a limited set of medical services according to the Asylum Seekers Benefits Act. This law established a two-class medical system with reduced access to treatment for asylum seekers and illegal migrants when it was enacted in 1993. It thus produces different national categories of membership and hence exclusion through the deprivation of rights. It becomes clear that the possibilities of inclusive urban policies are limited; they are "integrated into a global power structure and the nation-state remains an important 
terrain for political struggles" (Schilliger, 2019, p. 36). However, some authors point out the danger in that this could leave these actual exclusion mechanisms unquestioned and might even stabilize them (Blokland, Hentschel, Holm, Lebuhn, \& Margalit, 2015, p. 663; Hess \& Lebuhn, 2014, p. 19). The Medibüro is aware of this fact. It reminds us that both legislations serve as racist control instruments and that the contradictions between such exclusion mechanisms and practical solutions like the Anonymized Health Certificates need to be included in a critical analysis. They highlighted this contradiction when they campaigned for the implementation of the Anonymized Health Certificate program and at the same time for the abolition the Asylum Seekers Benefits Act (Medibüro, 2014). Accordingly, for the Medibüro, the implementation of Anonymized Health Certificate is only one step in the struggle for a health care system which provides the same medical care for everyone.

\section{Migratory Strategies and Everyday Performances of Urban Citizenship}

For illegalized migrants, the implementation of the Anonymized Health Certificate will definitely make a difference, as access to medical care in Berlin will become easier. Yet even without the Anonymized Health Certificate, illegalized migrants have developed different strategies in order to access the rights that they have been denied. While most studies on illegalized migrants living in Germany portrayed them as victims and highlighted the strenuous conditions and social exclusion (see, for example, Alt, 2003; Pater, 2005; Wilmes, 2011), we, in contrast, understand illegalized migrants as political subjects rather than victims (McNevin, 2013, p. 185; Squire, 2017, p. 255). Thus, in the following section we will focus on their strategies and argue that illegalized migrants become political subjects who perform urban citizenship in their everyday life. This does not mean that illegalized migrants have an easy life. On the contrary; pain, anxiety, and desperation are often part of their daily experience. As mentioned above, the nontreatment of diseases and injuries are part of the strategies they rely on. This can have serious consequences, as can be illustrated in the case of Kweku, who went to the doctor too late, both because he was afraid that his missing papers would be detected, and because he would have had to pay for the treatment himself:

I had an eye disease when I was in Germany. When I noticed it, I first thought it would go away on its own. But it didn't. It got worse so I decided to go to a doctor. She examined my eyes. It was not that bad, but they told me I needed a surgical procedure straightway. So I considered whether to get the operation or to keep my money and my job and wait watchfully. I took the second option, which was the wrong one. (Interview, Kweku)
The initial disease was relatively easy to treat. But the non-treatment led to an aggravated situation, so that a complete recovery of the affected eye was no longer possible. Today, Kweku is nearly blind in one eye (Interview, Kweku). This demonstrates the brutal consequences for illegalized migrants of the exclusion mechanisms in the health care system described above. Yet there are also other strategies than non-treatment. Social networks are an important factor for access to medical care. One strategy is to borrow a health insurance card, ideally from a person with similar key data, such as the same gender and a comparable age:

I shared the insurance card with a friend. It was his card. He had official papers.... always went to the same doctor. I already became familiar to him. He knew my name, which was the name of my friend....My friend went to another doctor. We had to be cautious with the card. Because if anybody had gotten scent of it, we both would have been in big trouble. (Interview, David)

All in all, this is a strategy that represents relatively lowrisk access to medical care. Since the introduction of the new insurance card with a photograph, a certain similarity must also be taken into account:

You can do the same with the new cards with the photo on it. Just the same hairstyle, otherwise I'm just a Black person for them. Nobody will recognize a difference. Besides, they never really look at it. (Interview, Laure)

For example, it is important to keep in mind that treatment methods are consistent with the health profile of the person who lends the card, because this could cause problems afterwards (cf. Anderson, 2003, p. 35). Care must also be taken to ensure that treatment patterns are not contradictory and thus refer to different medical histories, for example if an appendix has to be removed for the second time. In such cases, the attending doctors can become suspicious or the health insurance companies may check whether it is an insurance fraud, which may uncover the lack of official residency (Stobbe, 2004, p. 121).

In addition to the lending of health insurance cards, the social networks also ensure access to medical care in other ways. Vida and Mary both state that among their acquaintances there are doctors or medical professionals:

My friend's wife has a medical practice. I can go there. She examines you and gives you medication....There you don't have to be afraid that she will inform the authorities or call the police. (Interview, Vida)

My uncle worked in the pharmacy and studied medicine [in his country of origin]. He's doing some- 
thing different in Germany now, but if we get sick or have complaints, we can go to him and he'll help us. (Interview, Mary)

Mary's uncle has a legal residence status in Germany, yet his educational qualifications were not acknowledged, which is why he does not work in the medical field. However, according to Mary, he helps diagnose many people without papers and without health insurance. He also has some contacts with licensed doctors to whom he refers those he helps in "worse cases" (Interview, Mary). Vida's remarks illustrate the fear of deportation which is part of the everyday life of illegalized migrants. Therefore, it is essential to know doctors you can trust. The social networks are a key factor for this. Even if there aren't any trusted doctors in the community, there is often knowledge within the social networks about solidarity medical practices and hospitals that do not ask unpleasant questions:

I always go to a doctor after the office hours. She was recommended to me by my roommate, who said that many people go there and she is very friendly. (Interview, Josephine)

Through social networks, the information about the Medibüro as well as the organization known as the Malteser Migranten Medizin, is shared. Both are nongovernmental initiatives that connect illegalized migrants to solidarity doctors. Both are financed by donations, which means they have a limited budget. Not all medically necessary treatments can be carried out. Especially in the case of cost-intensive treatments, which require expensive equipment and medicine, long-term drug therapy, or inpatient treatment. The financial resources are quickly overstretched, so that the initiatives cannot provide sufficient prevention, diagnostics, and therapy (Groß, 2005, p. 24). Nevertheless, both organizations help to make health care accessible for those who are excluded from it, as Laure's statements demonstrate:

During pregnancy I had a midwife. She often came to my home and helped me a lot....Although we never spoke directly about papers, she knew about it. She then told me about the Malteser, which was a real relief for me. (Interview, Laure)

The Malteser Migranten Medizin organized the delivery in a Berlin hospital, as well as post-natal care and early childhood medical care for the baby (according to Laure). Nevertheless, not all illegalized migrants know about these two institutions.

However, we want to emphasize that there is a "situated knowledge"(Haraway, 1995) about trustworthy doctors, solidarity medical facilities, and initiatives like the Medibüro and the Malteser Migranten Medizin within the social networks. It is generated by experiences and the subsequent exchange and sharing of these experi- ences with others. As a "mobile common," this knowledge offers basic resources for living (and surviving) and everyday participation in society (Papadopoulos \& Tsianos, 2013, p. 190). These mobile commons circulate within social networks and are thereby continually updated and expanded upon. They are invisible goods that belong to no one and which cannot be controlled by anyone. Accordingly, this knowledge is not only a product of reoccurring experiences of migrant life, but also the prerequisite for everyday practices that allow (and produce) alternative forms of life (Bojadžijev, 2012, p. 147; Trimikliniotis, Parsanoglou, \& Tsianos, 2015, p. 1040). In this sense, mobile commons facilitate access to health care and are therefore practices of urban citizenship from below. Similarly, the practice of sharing insurance cards is another form of lived urban citizenship (Lister, 2007). We argue that illegalized migrants as resistance strategies simply 'take' their rights-rights which are not formally granted to them, but which should be their basic rights-yet still do not perform "acts of citizenship" as Isin (2008, p. 18) defines them. For him, those acts rupture prevailing perceptions of formal citizenship. Consequently, those people staging acts of citizenship "transform themselves (and others) from subjects into citizens as claimants of rights" (Isin, 2009, p. 368). This results in one becoming an activist citizen constituted though representation and visibility. But the previously mentioned strategies and practices of illegalized migrants do not rely on visibility. On the contrary, strategies of disembodiment and invisibility are part of their everyday struggles "to remain outside of the reaches of state authorities" (Rygiel, 2011, p. 157). To remain underground and to dis-identify with the existing categories of border regimes is an immanent act of resistance (Papadopoulos, Stephenson, \& Tsianos, 2008, pp. 217-218). They refuse their categorization as deportable and illegal subjects and thus become urban citizens, who participate in urban society without the formal rights to do so. Even if there are no visible and audible claims made, the strategies of exchanging specific knowledge and sharing insurance cards can be interpreted as everyday performances of urban citizenship, because at the end of the day they ensure societal participation and access to fundamental rights.

\section{Conclusion}

In summer 2019, the first Anonymous Health Certificates were issued to illegalized migrants in Berlin. The struggles and campaigns that have pushed the state government to work on the implementation are already a form of urban citizenship. As demonstrated, the Medibüro was a central actor in this process. It not only helps migrants to gain the most access possible through personal consultations and connecting them with solidarity medical institutions, but also uses these experiences to fight for political solutions. Their political work helps to sustain the imperceptible everyday practices of illegalized migrants. 
It both uncovers and challenges exclusionary practices in the public health system. Hence, it gives rise to a broader public discussion of what it means to have access to rights. Moreover, transformation processes towards a city that provides possibilities for participation for all its inhabitants regardless of their formal residency becomes conceivable. An urban citizenship perspective that scrutinizes the struggles for and processes of social change enables a nuanced analysis of the Anonymized Health Certificate. In this way, the actual possibility of providing people with concrete access to health care becomes tangible, without ignoring the exclusion mechanisms that are being circumvented in Berlin but are not contested at national level where they remain effective. Besides the struggles about the implementation of the Anonymized Health Certificate, the illegalized migrants themselves have ensured that they gain access to health care. Using the insurance cards of friends, going to solidarity doctors - who treat them for free-and spreading the word about them within their social networks are practices of urban citizenship. Even if they do not contest the social order visibly, they simply 'take' their rights to participate in society, imperceptibly, through those strategies and thus perform practices of urban citizenship in their everyday life.

\section{Conflict of Interests}

The authors declare no conflict of interests.

\section{References}

Alt, J. (2003). Leben in der Schattenwelt [Living in the shadow world]. Karlsruhe: Loeper.

Anderson, P. (2003). 'Dass Sie uns nicht vergessen...': Menschen in der Illegalität in München ['That they don't forget us...': People in illegality in Munich]. Munich: Landeshauptstadt München Sozialreferat.

Ataç, I., Rygiel, K., \& Stierl, M. (2016). Introduction. The contentious politics of refugee and migrant protest and solidarity movements: Remaking citizenship from the margins. Citizenship Studies, 20(5), 527-544.

Balibar, È. (2004). We the people of Europe? Reflections on transnational citizenship. Princeton, NJ: Princeton University Press.

Bartholome, B., Groß, J., \& Misbach, E. (2010). Neue Perspektiven in Berlin? [New perspectives in Berlin?]. Berliner Ärzte, 1, 22.

Bauder, H. (2016). Possibilities of urban belonging. Antipode, 48(2), 252-271.

Blokland, T., Hentschel, C., Holm, A., Lebuhn, H., \& Margalit, T. (2015). Urban citizenship and the right to the city: Fragmentations of claims. International Journal of Urban and Regional Research, 39(4), 655-665.

Bundesministerium des Innern. (2007). Illegal aufhältige Migranten in Deutschland: Datenlage, Rechtslage, Handlungsoptionen [Illegal migrants in Germany:
State of data, legal situation, options for action]. Berlin: Bundesministerium des Innern. Retrieved from https://www.einwanderer.net/fileadmin/ downloads/berichte/illegalitaet_-_bmi.pdf

Bojadžijev, M. (2012). Die windige Internationale. Rassismus und Kämpfe der Migration [The windy international: Racism and struggles of migration]. Münster: Westfälisches Dampfboot.

Darling, J. (2017). Forced migration and the city: Irregularity, informality and the politics of presence. Progress in Human Geography, 4(2), 178-198.

de Genova, N. (2002). Migrant 'illegality' and deportability in everyday life. Annual Review of Anthropology, 31, 419-447.

Dickel, P., \& Schröder, M. (2013). Vom Medibüro zur Poliklinik [From Medibüro to polyclinic: Health needs politics]. Zeitschrift für eine soziale Medizin, 1, 8-10.

Gilbert, L., \& Dikeç, M. (2008). Right to the city: Politics of citizenship. In K. Goonewardena, S. Kipfer, R. Milgrom, \& C. Schmid (Eds.), Space, difference, everyday life: Reading Henri Lefebvre (pp. 250-263). New York, NY: Routledge.

Groß, J. (2005). Möglichkeiten und Grenzen der medizinischen Versorgung von Patienten und Patientinnen ohne legalen Aufenthaltsstatus [Possibilities and limitations of medical care for patients without legal residence status]. Berlin: Flüchtlingsrat Berlin.

Groß, J. (2009). Patienten ohne Papiere-Es bewegt sich etwas [Patients without papers-Something is moving]. Berliner Ärzte, 2, 24-25.

Haraway, D. (1995). Die Neuerfindung der Natur. Primaten, Cyborgs und Frauen [Simians, cyborgs and women: The reinvention of nature]. Frankfurt am Main and New York, NY: Campus.

Hess, S., \& Lebuhn, H. (2014). Politiken der Bürgerschaft [Politics of citizenship]. Suburban, 3(2), 11-34.

Huschke, S. (2013). Kranksein in der Illegalität [IIlness in illegality]. Bielefeld: Transcript.

Isin, E. (2008). Theorizing acts of citizenship. In E. Isin \& G. Nielsen (Eds.), Acts of citizenship (pp. 15-43). London: Palgrave.

Isin, E. (2009). Citizenship in flux: The figure of the activist citizen. Subjectivity, 29(1), 367-388.

Lebuhn, H. (2014). Illegalisierung: Lokale Konflikte um Kontrollen, Rechte und Ressourcen [Illegalization: Local conflicts over checks, rights and resources]. In B. Belina, M. Naumann, \& A. Strüver (Eds.), Handbuch kritische Stadtgeographie [Handbook critical urban geography] (pp. 228-233). Münster: Westfälisches Dampfboot.

Lister, R. (2007). Inclusive citizenship: Realizing the potential. Citizenship Studies, 11(2), 49-61.

McNevin, A. (2013). Ambivalence and citizenship: Theorising the political claims of irregular migrants. Millennium: Journal of International Studies, 41(2), 182-200.

Medibüro. (2014). Gesundheit für alle: Asylbewerberleistungsgesetz abschaffen [Health for all: Abolish the 
welfare law for asylum seekers]. Berlin: Medibüro. Retrieved from http://stopasylblg.de/wp-content/ uploads/2014/11/2014_kampagne_gesundheit-undasylblg-2.pdf

Medibüro. (2016). 20 Jahre Medibüro [20 years Medibüro]. Berlin: Medibüro. Retrieved from https:// medibuero.de/wp-content/uploads/sites/10/2016/ 03/20_Jahre_Medibuero_Berlin_WEB.pdf

Medibüro. (2019). Aufruf zum Warnstreik: Gesundheit für alle! Anonymisierter Krankenschein jetzt! [Call for a warning strike: Health for all! Anonymous Health Certificate now!]. Medibüro. Retrieved from https:// medibuero.de/gesundheit-fuer-alle-anonymisierterkrankenschein-jetzt

Nicholls, W. (2016). Politicizing undocumented immigrants one corner at a time: How day laborers became a politically contentious group. International Journal of Urban and Regional Research, 40(2), 299-320.

Nyers, P. (2008). No one is illegal: Between city and nation. In E. Isin \& G. Nielsen (Eds.), Acts of citizenship (pp. 160-182). London and New York, NY: Zed Books. Nyers, P., \& Rygiel, K. (Eds.). (2012). Citizenship, migrant activism, and the politics of movement. Abingdon: Routledge.

Papadopoulos, D., Stephenson, N., \& Tsianos, V. (2008). Escape routes. London: Pluto Press.

Papadopoulos, D., \& Tsianos, V. (2013). After citizenship: Autonomy of migration, organisational ontology and mobile commons. Citizenship Studies, 17(2), 178-196.

Pater, S. (2005). Menschen ohne Papiere [People without papers]. Düsseldorf: Retap.

Rygiel, K. (2011). Governing borderzones of mobility through e-borders: The politics of embodied mobility. In V. Squire (Ed.), The contested politics of mobility: Borderzones and irregularity (pp. 143-168). London: Routledge.

Rygiel, K., Ataç, I., Köster-Eiserfunke, A., \& Schwiertz, H. (2015). Governing through citizenship and citizenship from below: An interview with Kim Rygiel.
Movements-Journal for Critical Migration and Border Regime Studies, 1(2). Retrieved from http:// movements-journal.org/issues/02.kaempfe/ 02.rygiel,ataç,köster-eiserfunke,schwiertz- $\bigvee$ governing-citizenship-from-below.html

Schilliger, S. (2018). Urban Citizenship: Teilhabe für alleDa, wo wir leben [Urban citizenship: Participation for all-Where we live]. In H. Aigner \& S. Kumnig (Eds.), Stadt für alle! Analysen und Aneignungen [City for all! Analyses and appropriations] (pp. 14-35). Vienna: Mandelbaum Verlag.

Schilliger, S. (2019). Undoing borders in solidarity cities. Global Dialogue-Magazine of the International Sociological Association, 3, 35-36.

Squire, V. (Ed.). (2011). The contested politics of mobility: Borderzones and irregularity. London: Routledge.

Squire, V. (2017). Unauthorised migration beyond structure/agency? Acts, interventions, effects. Politics, 37(3), 253-272.

Stobbe, H. (2004). Undokumentierte Migration in Deutschland und den Vereinigten Staaten [Undocumented migration in Germany and the United States]. Göttingen: Universitätsverlag Göttingen.

Trimikliniotis, N., Parsanoglou, D., \& Tsianos, V. (2015). Mobile commons and/in precarious spaces: Mapping migrant struggles and social resistance. Critical Sociology, 42(7), 1035-1049.

Wilcke, H. (2018). Illegal und unsichtbar? Papierlose Migrant*innen als politische Subjekte [IIlegal and invisible? Migrants without papers as political subjects]. Bielefeld: Transcript.

Wilmes, M. (2011). Irregular migration and foggy organisational structures. In M. Bommes \& G. Sciortino (Eds.), Foggy social structures: Irregular migration, European labour markets and the welfare state (pp. 117-140). Amsterdam: Amsterdam University Press.

Yuval-Davis, N., Wemyss, G., \& Cassidy, K. (2018). Everyday bordering, belonging and the reorientation of British immigration legislation. Sociology, 52(2), 228-224.

\section{About the Authors}

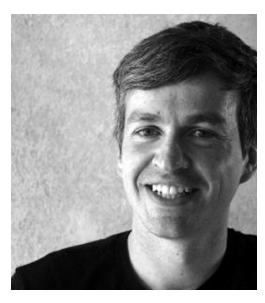

Holger Wilcke holds a PhD in Geography from the Humboldt University of Berlin. He is a Research Associate with the Berlin Institute for Integration and Migration Research (BIM) at Humboldt University of Berlin. His work focuses on migration and social movements as well as the politics of migratory struggles.

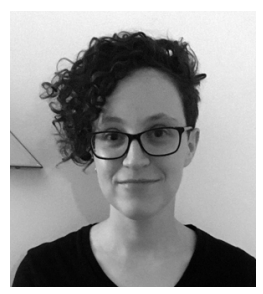

Rosa Manoim completed her MA in Migration and Displacement at the University of the Witwatersrand in Johannesburg, South Africa, before moving to Berlin to begin research for a PhD. Her work focuses on bureaucratic violence, citizenship, and uncertainty. 